\title{
Tenure for the Academic Librarian
}

\begin{abstract}
This paper outlines the purposes and history of academic freedom and tenure for teaching faculty and observes their value to the academic enterprise. It points further to the similar and growing need for such freedom and tenure for college and university librarians and cites examples of the ways in which their absence can affect institutions in deleterious ways. The paper envisions the increasing extension of tenure to academic librarians.
\end{abstract}

$\mathrm{T}$ HERE Is substantial evidence of a strong trend among academic librarians in the United States to gain full academic status within their institutions. The recent reclassification of librarians at the City University of New York, the organization of a Librarians' Association at the University of California, the endorsement of a statement on librarians' status by the Academic Senate of the California state colleges, and the sudden increase in the number of articles on the status of librarians in several of the library journals are all indications of a movement in this direction by many academic librarians.

Along with the demands for equal salaries, for sabbatical leaves, and for a voice in the academic structure of the colleges and universities they serve, librarians have also initiated discussions on their need for tenure if they are to perform as equals in the academic community. Historically, the development of the principle of tenure for faculty members dates back to the early years of this century when educators began to recognize that the dual role of institutions of higher learning could not be realized without guarantees of academic freedom for officers of instruction. That dual function has been described succinctly by Thomas I. Emerson, Professor of Law at Yale University, and David Ha-

Mrs. Blake is Gifts and Exchange Librarian at UCLA. ber, Professor of Law at Rutgers University, in their article "Academic Freedom of the Faculty Member as Citizen":

The university is generally conceived as performing two main functions in a democratic society. One is the transmission of existing knowledge and values to the oncoming generation. The other is the critical re-examination of such knowledge and values, with a view to facilitating orderly change in the society. ${ }^{1}$

To ensure the ability of the faculty member to carry out his obligations, the principle of academic freedom has gradually come to be widely accepted within the academic community and outside it. The principle of tenure is inseparable from that of academic freedom. Without employment security the freedom to seek out and proclaim the truth is merely a pretty sentiment. Justice Felix Frankfurter, in his decision in the case of McNabb vs. United States in 1943, stated that "the history of liberty has largely been the history of observance of procedural safeguards."

Probably the most authoritative statement in this field is the Statement of Principles on Academic Freedom and Tenure adopted by the American As-

\footnotetext{
1 Thomas I. Emerson and David Haber, "Academic Freedom of the Faculty Member as Citizen," Law and Contemporary Problems, XXVIII (Summer 1963), 547.

$2 \mathrm{McNabb}$ vs. United States, 318 U.S. 332,347 (1943), quoted in William P. Murphy, "Academic Freedom-an Emerging Constitutional Right," Law and Contemporary Problems, XXVIII (Summer 1963), 469-70.
} 
sociation of University Professors in 1940. It states:

Institutions of higher education are conducted for the common good and not to further the interest of either the individual teacher or the institution as a whole. The common good depends upon the free search for truth and its free exposition.

Academic freedom is essential to these purposes and applies to both teaching and research. Freedom in research is fundamental to the advancement of truth. Academic freedom in its teaching aspect is fundamental for the protection of the rights of the teacher in teaching and of the student to freedom in learning. It carries with it duties correlative with rights.

Tenure is a means to certain ends; specifically: (1) freedom of teaching and research and of extramural activities and (2) a sufficient degree of economic security to make the profession attractive to men and women of ability. Freedom and economic security, hence, tenure, are indispensable to the success of an institution in fulfilling its obligations to its students and to society. ${ }^{3}$

Since 1940 the Statement of Principles has been officially endorsed by some fifty prestigious scholarly associations, including the American Library Association, which endorsed the statement, adapted for librarians, in 1946. The endorsement has not yet been translated into practice for academic librarians, however. More than twenty years after the American Library Association endorsement, the academic librarian with tenure remains the exception rather than the rule.

How applicable are the protections implicit in tenure for the academic librarian? By most academic institutions the librarian is regarded as a member of the academic community-either formally in the personnel classification of the institution or informally by such tokens as admission to membership in faculty clubs, participation in faculty committees, or access to other faculty

s "1940 Statement of Principles on Academic Freedom and Tenure," AAUP Bulletin, LIII (June 1967), 246. perquisites. The college or university librarian plays two kinds of roles in the academic community. He functions in an ancillary capacity when he helps to develop the library as a functioning tool for the curriculum of his institution, in a primary capacity when he helps to determine the policies within the library itself and the policies governing the whole institution within which the library functions. And always, along with all other members of the total academic community, he is a citizen of the world outside the academic institution. Uncertainties about his status and employment security cannot help but affect his stance within and without the library since no one expects the librarian to be more courageous than his academic colleagues. Sometimes, surprisingly, even without protection, he is.

Because the academic librarian is rarely exposed to public censure in the same way as the public librarian for the kinds of materials he acquires-or fails to acquire-there is an unfortunate tendency to blur over the situations in which the librarian is censored or censors himself to avoid a possible confrontation. Cases in point could include: a copy of an order form signed by a librarian for an avant-garde journal with a somewhat earthy title was widely circulated in a conservative community as part of an effort to discredit the librarian. How many librarians failed to order the journal at all regardless of its possible value to a research collection? Another instance: a university librarian responsible for the extensive exchange program of her library was roundly belabored by telephone and in letters by a publisher for sending materials to China, Cuba, and the Soviet Union. How many librarians avoid such exchange arrangements altogether although the materials obtained may be invaluable additions to the collection? Or how many college and university librarians hesitate to solicit or buy publications from organizations of the far right and far left be- 
cause they are not sure of their positions if trouble should arise?

Within his professional associations the insecure position of the librarian can silently but quite effectively limit his willingness or ability to contribute new ideas, to espouse possibly unpopular positions, or to press effectively for the constant re-evaluation in which any responsible academic must participate. Often he finds himself faced with maintaining a position publicly either directly under the gaze of his own administrator or, at times, directly in opposition to that administrator. How many times has he remained silent to the detriment of the college or university library and ultimately of the college or university itself?

Academic librarians have not notably participated vigorously and publicly in the broad citizen movements of our time in contrast to the often very effective efforts by their colleagues on the faculty. The opposition to the repressive measures of the late unlamented McCarthy era, the contributions, such as they are, by intellectuals to the civil rights movement of the last decade, the responsible scholarship around the problems of peace have not come for the most part from academic librarians. The academic librarian's freedom to investigate and publicize positions on matters of public interest is seriously eroded by his unprotected employment status. Henry Wriston has written:

The source of tenure is its relationship to academic freedom. Tenure is regarded as a major guarantee of freedom because it puts the instructor beyond the easy reach of ad- ministrative tyranny or the quixotism of governing boards. . . . If freedom is the mark of strength, tenure is its symbol. For tenure is the guarantee to the individual that his freedom is real and not a shadow. ${ }^{4}$

One of the problems in the extension of tenure to the academic librarian lies in the reluctance of both faculty members and librarians themselves to accept the need for the responsibilities and the rights implicit in the concept of tenure. Faculty members tend to guard tenure jealously-as they should-but they often fail to recognize the fact that academic librarians have become their colleagues in the world of scholarship. Today's academic librarian deals with a complex and demanding book world. He finds his way-and the student's and professor's-through a publication explosion which has quintupled in less than a decade; he is adapting a whole new area of technological advances to library uses; he has specialized in depth by both advanced education and close collaboration with the faculty in innumerable subject specializations; he handles publications in several languages. Not all academic librarians value themselves soundly. Some, drilled in an earlier school, see themselves only as subservient to faculty and administrators. Some, out of timidity, fear all change. But there are also a sizable and increasing number who recognize the fact that tenure for themselves and for future academic librarians will improve the educational process and who are determined to explore the means for attaining it.

"Henry M. Wriston, "Academic Tenure," The American Scholar, IX (Summer 1940), 339, 344. 